\title{
Subthreshold concentration of endothelin-1-enhanced, capsaicin-induced bronchoconstriction in anaesthetized guinea-pigs
}

\author{
H. Kanazawa, H. Fujiwara, K. Hirata, J. Yoshikawa
}

\begin{abstract}
Subthreshold concentration of endothelin-1-enhanced, capsaicin-induced bronchoconstriction in anaesthetized guinea-pigs. H. Kanazawa, H. Fujiwara, K. Hirata, J. Yoshikawa. CERS Journals Ltd 1998.

ABSTRACT: An increasing number of studies have been performed to address a possible role for endothelin-1 (ET-1) as a significant mediator in asthma. However, the effects of subthreshold concentrations of ET-1, which cannot elicit bronchial smooth muscle contraction itself, in asthma has yet to be determined. This study determined these effects of ET-1 on capsaicin-induced bronchoconstriction in anaesthetized guinea-pigs.

Aerosolized ET-1 administered at doses of $10^{-9} \mathrm{M}$ and higher induced a dosedependent increase in pulmonary resistance, but ET-1 at $10^{-10} \mathrm{M}$ did not have any bronchoconstrictive effect. However, this subthreshold concentration of ET-1 potentiated capsaicin-induced bronchoconstriction. In addition, the potentiation of capsaicin-induced bronchoconstriction by this subthreshold concentration of ET-1 was completely abolished by BQ788 (ETB receptor antagonist), but not BQ123 (ETA receptor antagonists). Immunoreactive substance $\mathbf{P}$ (SP) levels in bronchoalveolar lavage fluid after capsaicin administration were significantly higher than those after solvent administration. However, ET-1 alone did not significantly stimulate immunoreactive SP release and ET-1 $\left(10^{-10} \mathrm{M}\right)$ did not potentiate capsaicin-induced immunoreactive SP release. In contrast, ET-1 $\left(1^{-10} \mathrm{M}\right)$ potentiated exogenous neurokinin A- and SPinduced bronchoconstriction.

These findings suggest that a subthreshold concentration of endothelin-1 does not potentiate the tachykinin release induced by capsaicin but the airway smooth muscle contraction through endothelin-B receptors.
\end{abstract}

Eur Respir J 1998; 12: 1307-1312.

First Dept of Internal Medicine, Osaka City University Medical School, Osaka, Japan.

Correspondence: H. Kanazawa First Dept of Internal Medicine Osaka City University Medical School 1-4-3, Asahi-machi, Abenoku

Osaka, 545-8585

Japan

Fax: 8166453802

Keywords: Airway C-fibre endothelin receptor antagonist tachykinin

Received: November 201997 Accepted after revision July 161998
Endothelin-1 (ET-1) is a 21 amino acid peptide originally isolated from porcine endothelial cells [1], which has potent spasmogenic activity in both vascular and airway smooth muscle $[1,2]$. Bronchial asthma is an inflammatory airway disorder characterized by bronchoconstriction and bronchial hyperreactivity. Recent observations suggest that an increased intrapulmonary production of ET-1 may specifically occur in asthma. The bronchial epithelium of asthmatic patients has been found to express preproendothelin-1 messenger ribonucleic acid (mRNA) [3], to contain endothelin immunoreactivity [4] and to release large amounts of ET-1 [5]. The high potency of ET-1 in inducing contraction of airway smooth muscle both in vivo and in vitro $[2,6]$ led to the assumption that it may play an important role in the pathogenesis of asthma. However, the precise mechanisms through which ET-1 causes bronchoconstriction are unclear. Moreover, it should be stressed that the amount of ET-1 recovered in the bronchoalveolar lavage (BAL) fluid of patients with asthma is quite low compared with the dose of ET-1 found to be effective in eliciting bronchial smooth muscle contraction [7]. It was previously found that a subthreshold concentration of ET1 which was not able to elicit bronchial smooth muscle contraction markedly augmented the magnitude and dura- tion of bronchoconstriction caused by other mediators, such as histamine [8].

The pulmonary airways of rodents and humans are innervated with sensory C-fibres [9], which provide an afferent pathway for central neural reflex control of airway functions. These neurons also synthesize and store neuropeptides in granules found within their terminal varicosities. A variety of chemical, physical and electrical stimuli can cause sensory C-fibres to release their neuropeptides locally into innervated structures, where these substances often initiate important physiological effects. In the airways, C-fibre stimulation causes the release of two classes of neuropeptides, tachykinins including substance P (SP) and neurokinin A (NKA), and calcitonin-gene related peptide (CGRP) [10]. Capsaicin is thought to stimulate pulmonary and bronchial C-fibre endings directly [11] and has been used as a research tool to identify C-fibre endings. Furthermore, activation of capsaicin-sensitive C-fibres leads to the local release of sensory neuropeptides. It is well known that sensory neuropeptides mimic many of the pathological features of bronchial asthma, including bronchospasm [12], plasma protein extravasation [13], inflammatory cell recruitment [14] and hypersecretion [15] and it has been suggested that overexcitation of sensory fibres 
is involved in the pathogenesis of bronchial asthma [16]. This study was designed to determine the physiological roles of subthreshold concentration of ET-1 on capsaicininduced bronchoconstriction in anaesthetized guinea-pigs.

\section{Materials and methods}

\section{Measurement of pulmonary resistance and aerosol gener- ation}

Male Hartley guinea-pigs weighing 400-500 g were used. Under sodium pentobarbital anaesthesia (Abbott Laboratories, North Chicago, IL, USA) (50 mg.kg-1, i.p.), artificial ventilation was performed through a tracheal cannula connected to a constant-volume ventilator (Model 680; Harvard Apparatus Co., South Natick, MA, USA) at a rate of 60 breaths $\cdot \mathrm{min}^{-1}$. The tidal volume was set at $6 \mathrm{~mL} \cdot \mathrm{kg}-1$. Airflow was monitored continuously with a pneumotachograph (TV-241T; Nihon Koden Co., Tokyo, Japan) connec-ted to a differential pressure transducer (TP-602T; Nihon Koden). The tidal volume was calculated by electrical integration of airflow. A fluid-filled polyethylene catheter was introduced into the oesophagus to measure oesophageal pressure as an approximation of pleural pressure. In-tratracheal pressure was measured using a polyethylene catheter inserted into the short tube connecting the tracheal cannula to the pneumotachograph. Transpulmonary pressure (defined as the difference between the intratracheal and the oesophageal pressure) was measured with a differential pressure transducer. Total pulmonary resistance $(R \mathrm{~L})$ was calculated using methods described previously [17]. Before experiments were performed, guinea-pigs were allowed $20 \mathrm{~min}$ to recover from the preparation procedure. To prevent alveolar atelectasis, a large inflation of three tidal volumes was performed every 5 min by occluding the expiratory valve. Drug aerosols (mass median aerodynamic diameter $1.8 \mu \mathrm{M}$ (geometric SD: $2 \mu \mathrm{M}$ ); output $\left.1.5 \mathrm{~mL} \cdot \mathrm{min}^{-1}\right)$ were generated by an ultrasonic nebulizer (TUR-3200; Nihon Koden) placed in the inspiratory line of the ventilator. Because capsaicin activates cholinergic reflexes [18], atropine $\left(1 \mu \mathrm{mol} \cdot \mathrm{kg}^{-1}\right)$ was routinely administered $15 \mathrm{~min}$ before drug challenge in all animals.

\section{Effect of endothelin-1 on capsaicin-induced bronchocon- striction}

The concentration response of $R \mathrm{~L}$ to ET- 1 administration was determined using the following method. After a control challenge with the solvent used to prepare ET-1, aerosolized ET-1 was administered (40 breaths at each concentration). RL was measured $60 \mathrm{~s}$ after the end of ET1 administration, when the bronchoconstrictor response reached its maximum. In subsequent experiments, guineapigs were exposed to ET-1 (10-10 M, 40 breaths) and 5 min later to capsaicin $\left(2 \times 10^{-6} \mathrm{M}\right.$ or $4 \times 10^{-6} \mathrm{M}, 40$ breaths at each concentration). The time of exposure to capsaicin was defined as time 0 . In another set of experiments, the inhibitory effects of endothelin receptor antagonists on capsaicin-induced bronchoconstriction following pretreatment with ET-1 $\left(10^{-10} \mathrm{M}\right)$ were evaluated. Guinea-pigs were exposed to BQ123 (10-5 M, 40 breaths) or BQ788 (10-5 M, 40 breaths) and 5 min later to ET-1 (10-10 M, 40 breaths). In following experiments, a specific peptide leukotriene antagonist (ONO-1078, $1 \mathrm{mg} \cdot \mathrm{kg}^{-1}$ ), thromboxane $\mathrm{A}_{2}$ $\left(\mathrm{TxA}_{2}\right.$ ) antagonist $\left(\mathrm{S}-1452,0.1 \mathrm{mg} \cdot \mathrm{kg}^{-1}\right)$, histamine antagonist (diphenhydramine, $10 \mathrm{mg} \cdot \mathrm{kg}^{-1}$ ) and cyclooxygenase inhibitor (indomethacin, $1 \mathrm{mg} \cdot \mathrm{kg}^{-1}$ ) were given in-travenously. Ten minutes after administration of these agents, guinea-pigs were exposed to ET-1 $\left(10^{-10} \mathrm{M}\right)$ and 5 min later to capsaicin $\left(2 \times 10^{-6} \mathrm{M}\right)$ (time o). In a prelimin-ary study, it was determined that administration of BQ788 $\left(10^{-5} \mathrm{M}\right)$ completely antagonized the contractile activity of ET-1 (10-9 or $\left.10^{-8} \mathrm{M}\right)$.

\section{Measurement of immunoreactive substance $P$}

Immunoreactive SP was measured by the following method, as described previously [19]. Guinea-pigs were exposed to saline or ET-1 $\left(10^{-10}\right.$ or $10^{-7} \mathrm{M}, 40$ breaths at each concentration) and 5 min later to capsaicin $\left(4 \times 10^{-6}\right.$ M, 40 breaths). Guinea-pigs were killed by exsanguination through the carotid artery $2.5 \mathrm{~min}$ after capsaicin administration. Saline $\left(5 \mathrm{~mL}, 37^{\circ} \mathrm{C}\right)$ was then instilled into the lung and lavage was repeated three times. Recovered BAL fluid was immediately mixed with $1 \mathrm{~mL}$ inhibitor solution $\left(2 \times 10^{-5} \mathrm{M}\right.$ neutral endopeptidase inhibitor phosphoramidon, $500 \mathrm{KIU} \cdot \mathrm{mL}^{-1}$ serine protease inhibitor aprotinin and $1.2 \mathrm{mg} \cdot \mathrm{mL}^{-1}$ of ethylenediaminetetraacetic acid (EDTA)) to avoid SP degradation and stored at $-70^{\circ} \mathrm{C}$ until assay. Cells were sedimented by centrifugation at $200 \times g$ for $10 \mathrm{~min}$ at $4^{\circ} \mathrm{C}$. The supernatant obtained was loaded on reversed-phase $\mathrm{C}_{18}$ cartridges (Sep-Pak $\mathrm{C}_{18}$; Millipore, Milford, MA, USA). After washing with $20 \mathrm{~mL} 4 \%$ acetic acid ( $\mathrm{pH} 4.0)$ and $20 \mathrm{~mL}$ distilled water, SP was eluted with $2 \mathrm{~mL} 80 \%$ acetonitrile in $0.1 \%$ tri-fluoroacetic acid. Eluates were concentrated by spin-vacuum evaporation, lyophilized, and dissolved with $0.15 \mathrm{~mL}$ assay buffer $(50$ $\mathrm{nM}$ phosphate buffer, $\mathrm{pH} 7.2$, containing $3.7 \mathrm{mg} \cdot \mathrm{mL}^{-1}$ EDTA and $0.5 \%$ bovine serum albumin). A total of 0.1 $\mathrm{mL}$ of the dissolved preparation was subjected to further radioimmunoassay (RIA) for SP. RIA for SP was performed using 125I-labelled SP (Amersham International, Amersham, UK) and anti-SP rabbit serum (Amersham International). The possible cross-reactivity of the SP-antibody with other tachykinins was $1 \%$ for NKA. A total of $0.1 \mathrm{~mL}$ sample was mixed with $0.5 \mathrm{~mL}$ assay buffer, $0.1 \mathrm{~mL}$ antiserum, and $0.1 \mathrm{~mL}{ }^{125} \mathrm{I}-\mathrm{SP}$ and stored at $4^{\circ} \mathrm{C}$ for $24 \mathrm{~h}$. A $0.2 \mathrm{~mL}$ suspension of dextran, charcoal ( $0.2 \%$ dextran and $2 \%$ activated charcoal in assay buffer) was added to the reaction mixture and centrifuged at $200 \times g$ for $10 \mathrm{~min}$. The radioactivity of the supernatant was measured by a gamma counter (Auto-Gamma 5550, Packard Instrument Co, Chicago, IL, USA). In this system, the sensitivity of immunoassayable SP in saline was $1-150 \mathrm{fmol} \cdot \mathrm{mL}^{-1}$. Using this protocol, the recovery of added radiolabelled SP was $85-90 \%$.

Effect of endothelin-1 on substance $P$ - and neurokinin A-induced bronchoconstriction

Guinea-pigs were exposed to ET-1 $\left(10^{-10} \mathrm{M}\right)$ and $5 \mathrm{~min}$ later to NKA $\left(5 \times 10^{-4} \mathrm{M}, 40\right.$ breaths $)$ or $\mathrm{SP}\left(5 \times 10^{-4} \mathrm{M}, 40\right.$ 
breaths). The effect of ET-1 was evaluated 5 min after NKA or SP administration. In the following experiments, the inhibitory effects of BQ788 on exogenous tachykinininduced bronchoconstriction following pretreatment with ET-1 were also evaluated.

Effect of endothelin-1 on acetylcholine-induced bronchoconstriction

Guinea-pigs were exposed to ET-1 $\left(10^{-10} \mathrm{M}\right)$ and 5 min later to acetylcholine $\left(1 \times 10^{-3}, 3 \times 10^{-3}\right.$ and $5 \times 10^{-3} \mathrm{M} ; 40$ breaths at each concentration). The effect of ET-1 was evaluated 5 min after acetylcholine administration.

\section{Drugs}

Capsaicin, diphenhydramine and indomethacin were obtained from Sigma Chemical Co. (St Louis, MO, USA). NKA, SP and ET-1 were purchased from Peptide Institute (Osaka, Japan). Cyclo (D-Trp-D-Asp-L-Pro-D-Val-L-Leu) (BQ123) and N-cis-2, 6-dimethylpiperidinocarbonyl-L$\gamma$-methyleucyl-D-methoxycarbonyltryptophanyl-D-norleucine (BQ788) were purchased from RBI (Natick, MA, USA). BQ123 and BQ788 were dissolved in ethanol and further dilutions were performed in $0.9 \%$ saline. 4-OXO8-[P-(4-phenylbutyloxy) benzoylamino]-2-(tetrazol-5-yle) -4H-1-benzopyran hemihydrate (ONO-1078) and calcium $5(\mathrm{Z})-1 \mathrm{R}, 2 \mathrm{~S}, 3 \mathrm{~S}, 4 \mathrm{~S}-7-[3$ phenylsulphonylaminobicyclo $[2,2,1]$ hept-2-yl]-5-heptenoate hydrate (S-1452) were kindly provided by ONO Pharmaceutical Co. (Osaka, Japan) and Shionogi Pharmaceutical, Osaka, Japan), respectively.

\section{Statistical analysis}

All values are expressed as mean \pm SEM. The statistical significance was determined by analysis of variance (ANOVA); $\mathrm{p}<0.05$ was considered significant. When ANOVA disclosed a significant difference, the Newman-Keuls test was used to determine which groups were significantly different from each other.

\section{Results}

The baseline $R \mathrm{~L}$ after administration of solvent alone was $0.18 \pm 0.02 \mathrm{cmH}_{2} \mathrm{O} \cdot \mathrm{mL}^{-1} \cdot \mathrm{s}^{-1}$ and aerosolized ET- 1 administration resulted in a dose-dependent increase in $R \mathrm{~L}$ (fig. 1). However, ET-1 (10-10 M) did not have any bronchoconstrictive effect.

Aerosolized capsaicin $\left(2 \times 10^{-6} \mathrm{M}\right)$ administration did not significantly increase $R$ L compared with solvent alone, but this concentration of capsaicin significantly increased $R \mathrm{~L}$ following pretreatment with a subthreshold concentration of ET-1 $\left(10^{-10} \mathrm{M}\right)$ (table 1$)$. In addition, capsaicin $\left(4 \times 10^{-6}\right.$ M) significantly increased $R$ L compared with solvent alone, and a subthreshold concentration of ET-1 markedly potentiated capsaicin $\left(4 \times 10^{-6} \mathrm{M}\right)$-induced bronchoconstriction. The solvent used for BQ123 and BQ788 had no effect

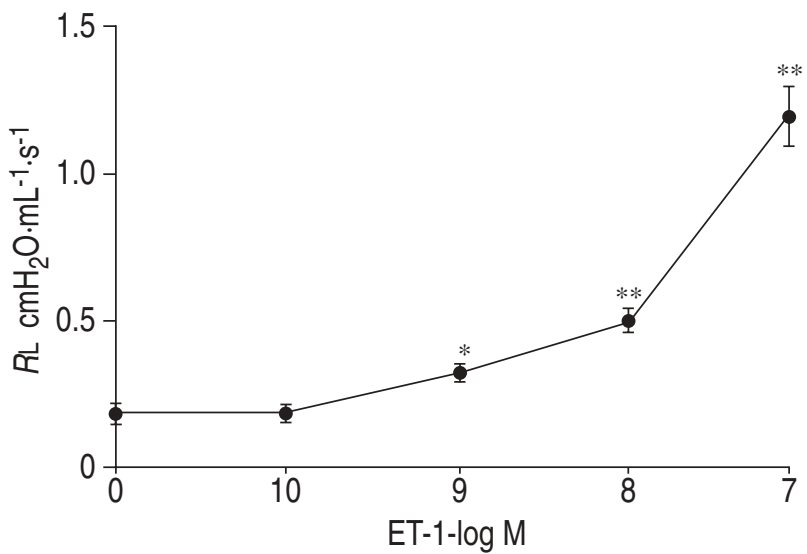

Fig. 1. - Dose-response curve of endothelin-1 (ET-1)-induced bronchoconstriction. RL: pulmonary resistance. Each point represents the mean \pm SEM for six animals. $*: \mathrm{p}<0.05, * *: \mathrm{p}<0.01$ compared with solvent alone.

on capsaicin-induced bronchoconstriction. BQ788, but not BQ123, significantly inhibited capsaicin $\left(4 \times 10^{-6} \mathrm{M}\right)$ induced bronchoconstriction following pretreatment with a subthreshold concentration of ET-1 (fig. 2). However, receptor antagonists of leukotriene, thromboxane $\mathrm{A}_{2}$, and histamine had no significant effects on the potentiation by ET-1 of capsaicin-induced bronchoconstriction. Moreover, the cyclooxygenase inhibitor had no effect on this potentiation by ET-1 (table 2).

Immunoreactive SP levels in BAL fluid after capsaicin administration were significantly higher than those after solvent administration (48 $\pm 7 \mathrm{fmol} \cdot \mathrm{L}^{-1}$ for solvent and $120 \pm$ $20 \mathrm{fmol} \cdot \mathrm{L}^{-1}$ for $4 \times 10^{-6} \mathrm{M}$ capsaicin; $\mathrm{p}<0.01$ ) (fig. 3). ET-1 (10-10 or $\left.10^{-7} \mathrm{M}\right)$ alone did not induce significant release of immunoreactive SP. Moreover, ET-1 $\left(10^{-10} \mathrm{M}\right)$ did not potentiate capsaicin-induced immunoreactive SP release. NKA $\left(5 \times 10^{-4} \mathrm{M}\right)$ and $\mathrm{SP}\left(5 \times 10^{-4} \mathrm{M}\right)$ each induced significant increases in $R \mathrm{~L}\left(0.45 \pm 0.05\right.$ and $0.35 \pm 0.05 \mathrm{cmH}_{2} \mathrm{O} \cdot \mathrm{mL}^{-1} \cdot \mathrm{s}$, respectively) (fig. 4). ET-1 $\left(10^{-10} \mathrm{M}\right)$ significantly potentiated exogenous NKA- and SP-induced bronchoconstriction. Although the solvent used for BQ788 had no effect on tachykinin-induced bronchoconstriction, BQ $788\left(10^{-5}\right.$ M) could completely inhibit the potentiation by ET-1 (10-10 M) of NKA or SP-induced bronchoconstriction. More-

Table 1. - Effect of subthreshold concentration of endothelin-1 (ET-1) on capsaicin-induced bronchoconstriction

\begin{tabular}{|c|c|c|c|c|}
\hline & \multicolumn{4}{|c|}{$R \mathrm{~L} \quad \mathrm{cmH}_{2} \mathrm{O} \cdot \mathrm{mL}^{-1} \cdot \mathrm{s}$} \\
\hline & $2.5 \mathrm{~min}$ & $5 \mathrm{~min}$ & $7.5 \mathrm{~min}$ & $10 \mathrm{~min}$ \\
\hline Solvent & $0.19 \pm 0.02$ & $0.19 \pm 0.02$ & $0.18 \pm 0.02$ & $0.18 \pm 0.02$ \\
\hline $\begin{array}{l}\text { Capsaicin } \\
\left(2 \times 10^{-6} \mathrm{M}\right)\end{array}$ & $0.27 \pm 0.05$ & $0.25 \pm 0.04$ & $0.22 \pm 0.02$ & $0.20 \pm 0.02$ \\
\hline $\begin{array}{l}\text { Capsaicin } \\
\left(4 \times 10^{-6} \mathrm{M}\right)\end{array}$ & $0.74 \pm 0.11$ & $0.61 \pm 0.09$ & $0.42 \pm 0.07$ & $0.34 \pm 0.05^{\dagger}$ \\
\hline $\begin{array}{l}\text { ET-1 }\left(10^{-10} \mathrm{M}\right) \\
+ \text { Capsaicin }\end{array}$ & & & & \\
\hline $\begin{array}{l}\left(2 \times 10^{-6} \mathrm{M}\right) \\
+ \text { Capsaicin } \\
\left(4 \times 10^{-6} \mathrm{M}\right)\end{array}$ & $0.41 \pm 0.07 *$ & $0.40 \pm 0.06 *$ & $0.38 \pm 0.04 *$ & $0.36 \pm 0.03 *$ \\
\hline & $1.27 \pm 0.21 \mp$ & $0.91 \pm 0.11$ & $0.81 \pm 0.10$ & $0.74 \pm 0.08$ \\
\hline
\end{tabular}

Each value represents the mean \pm SEM for six animals. $R \mathrm{~L}$ : pulmonary resistance. $t: \mathrm{p}<0.05 ;$; $\mathrm{p}<0.01$, compared with solvent alone; *: $\mathrm{p}<0.05$ compared with capsaicin $\left(2 \times 10^{-6} \mathrm{M}\right)$ alone; $:$ $\mathrm{p}<0.01$ compared with capsaicin $\left(4 \times 10^{-6} \mathrm{M}\right)$ alone. 


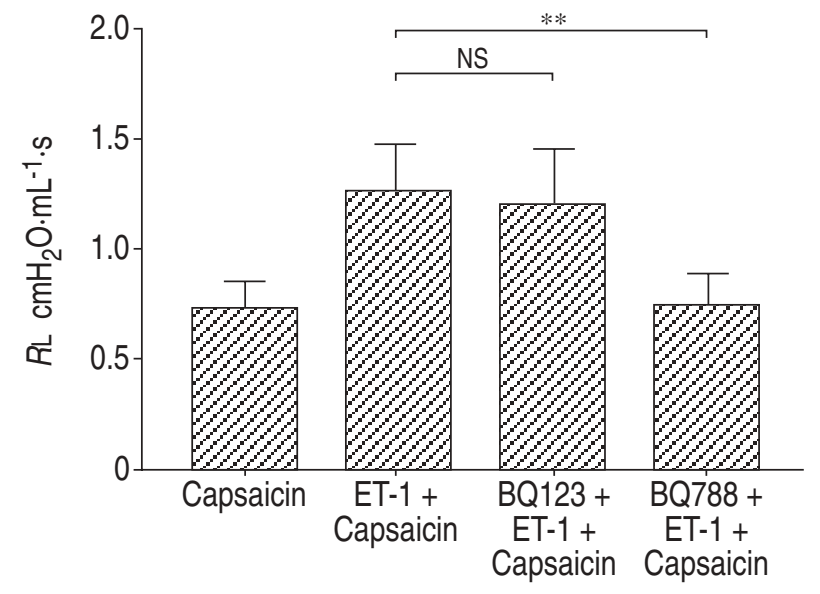

Fig. 2. - Inhibitory effects of endothelin (ET)A (BQ123) or ETB (BQ788) receptor antagonists (both $\left.10^{-5} \mathrm{M}\right)$ on capsaicin-induced $\left(4 \times 10^{-6}\right.$ M) bronchoconstriction following pretreatment with ET-1 $\left(10^{-10} \mathrm{M}\right)$. $R$ L: pulmonary resistance. Each column corresponds to 2.5 min after capsaicin administration and represents the mean \pm SEM for six animals. $* *$ : $\mathrm{p}<0.01$.

over, ET-1 $\left(10^{-10} \mathrm{M}\right)$ significantly potentiated acetylcholine-induced bronchoconstriction (fig. 5).

\section{Discussion}

Activation of airway C-fibres by capsaicin causes the release of neuropeptides, resulting in bronchoconstriction. In this study, a subthreshold concentration of ET-1 was found to potentiate capsaicin-induced bronchoconstriction. This subthreshold concentration of ET-1 did not potentiate the release of SP immunoreactivity stimulated by capsaicin and exogenous tachykinin administration markedly enhanced bronchoconstriction following pretreatment with a subthreshold concentration of ET-1. These findings suggest that although a subthreshold concentration of ET-1 does not stimulate tachykinin release from capsaicin-sensitive nerve endings, this dose of ET-1 enhances tachykinin-induced bronchoconstriction at postjunctional levels.

Previous studies have revealed potential mechanisms via which ET-1 may induce bronchoconstriction either through a direct effect on airway smooth muscle; or through an indirect effect secondary to mediator release. ET-1

Table 2. - Effect of receptor antagonists of leukotriene, thromboxane $\mathrm{A}_{2}$ and histamine and cyclooxygenase inhibitor on the potentiation by endothelin-1 (ET-1) of capsaicin-induced bronchoconstriction

\begin{tabular}{ccccc}
\hline & \multicolumn{4}{c}{$R \mathrm{~L} \mathrm{cmH} \mathrm{C}_{2} \cdot \mathrm{mL}^{-1} \cdot \mathrm{s}$} \\
\cline { 2 - 5 } & $2.5 \mathrm{~min}$ & $5 \mathrm{~min}$ & $7.5 \mathrm{~min}$ & $10 \mathrm{~min}$ \\
\hline $\begin{array}{c}\mathrm{ONO}-1078 \\
\left(1 \mathrm{mg} \cdot \mathrm{kg}^{-1}\right)\end{array}$ & $0.36 \pm 0.08$ & $0.39 \pm 0.07$ & $0.40 \pm 0.06$ & $0.40 \pm 0.05$ \\
$\mathrm{~S}-1452$ & & & & \\
$\left(0.1 \mathrm{mg} \cdot \mathrm{kg}^{-1}\right)$ & $0.38 \pm 0.07$ & $0.40 \pm 0.04$ & $0.40 \pm 0.04$ & $0.40 \pm 0.04$ \\
$\begin{array}{c}\text { Diphenhydramine } \\
\left(10 \mathrm{mg} \cdot \mathrm{kg}^{-1}\right)\end{array}$ & $0.41 \pm 0.06$ & $0.42 \pm 0.05$ & $0.41 \pm 0.05$ & $0.41 \pm 0.05$ \\
$\begin{array}{c}\text { Indomethacin } \\
\left(1 \mathrm{mg} \cdot \mathrm{kg}^{-1}\right)\end{array}$ & $0.39 \pm 0.07$ & $0.39 \pm 0.07$ & $0.40 \pm 0.07$ & $0.42 \pm 0.06$ \\
\hline
\end{tabular}

Each value represents the mean \pm SEM for five animals. $R$ L: pulmonary resistance. ONO-1078, S-1452, diphenhydramine and indomethacin had no significant effects on the potentiation by ET-1 of capsaicin $\left(2 \times 10^{-6} \mathrm{M}\right)$-induced bronchoconstriction.

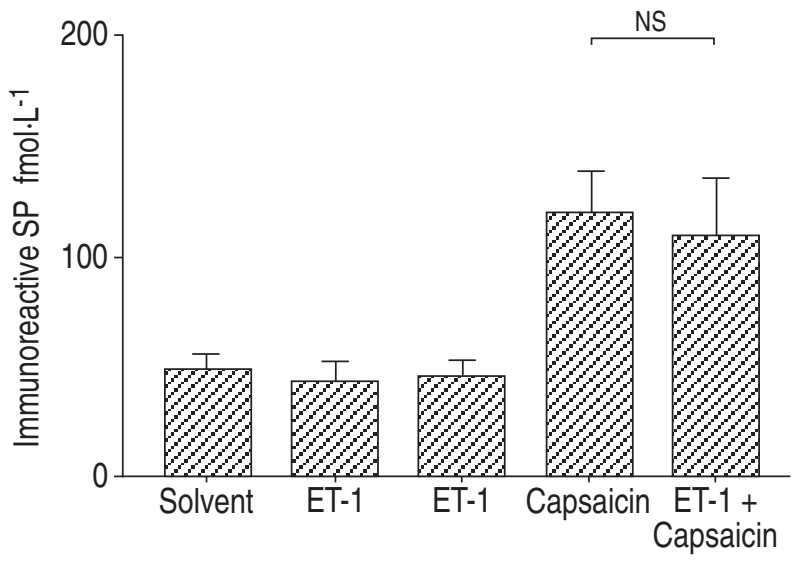

Fig. 3. - Effects of endothelin-1 (ET-1; 10-10 M) on capsaicin-induced $\left(4 \times 10^{-6} \mathrm{M}\right)$ immunoreactive substance $\mathrm{P}(\mathrm{SP})$ levels in bronchoalveolar lavage fluid. Each column corresponds to $2.5 \mathrm{~min}$ after capsaicin administration and represents the mean \pm SEM for seven animals. The immunoreactive SP level after administration of capsaicin was significantly higher than that after solvent alone $(\mathrm{p}<0.01)$.

increases intracellular calcium and activates phospholipase $\mathrm{C}$, generating inositol-triphosphate and diacylglycerol in human bronchial smooth muscle cells [20]. In guinea-pig airways, partial inhibition of ET-induced contraction can be obtained by preincubation with nifedipine [21]. Tachykinins released by capsaicin possibly induce the increase in intracellular $\mathrm{Ca}^{2+}$ levels in airway smooth muscle cells. Consequently, ET-1 and tachykinins would concomitantly stimulate the influx of $\mathrm{Ca}^{2+}$ into airway smooth muscle cells and $\mathrm{Ca}^{2+}$ release from sarcoplasmic reticulum, and enhance the contraction of airway smooth muscle. In guinea-pig trachea, $\mathrm{TxA}_{2}$, platelet-activating factor (PAF), leukotriene and adenosine have been suggested as secondary mediators of ET-1-induced bronchoconstriction [22, 23]. However, $\mathrm{TxA}_{2}$, PAF, leukotriene and histamine receptor antagonists did not affect ET-1-induced contraction in human isolated bronchi [24].

In this study, receptor antagonists of leukotriene, $\mathrm{TxA}_{2}$ and histamine, and cyclooxygenase inhibitor were shown to have no significant effects on the potentiation by a low dose of ET-1 of capsaicin-induced bronchoconstriction. These findings suggest that a low dose of ET-1 may affect guinea-pig bronchi predominantly through a direct effect.

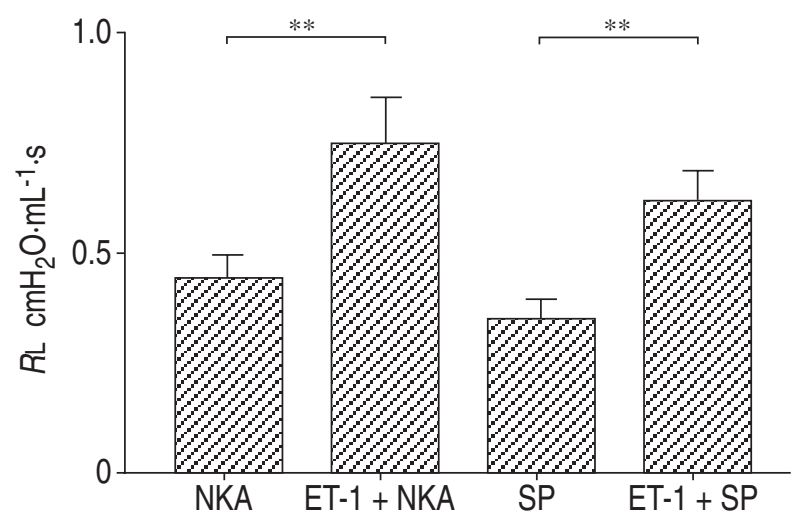

Fig. 4. - Effects of endothelin-1 (ET-1; 10-10 M) on neurokinin A (NKA; $5 \times 10^{-4} \mathrm{M}$ ) and substance $\mathrm{P}(\mathrm{SP})$-induced bronchoconstriction $\left(5 \times 10^{-4} \mathrm{M}\right)$. $R \mathrm{~L}$ : pulmonary resistance. Each column shows results obtained at $2.5 \mathrm{~min}$ after tachykinin administration and represents the mean \pm SEM for six animals. $* *$ : $\mathrm{p}<0.01$. 


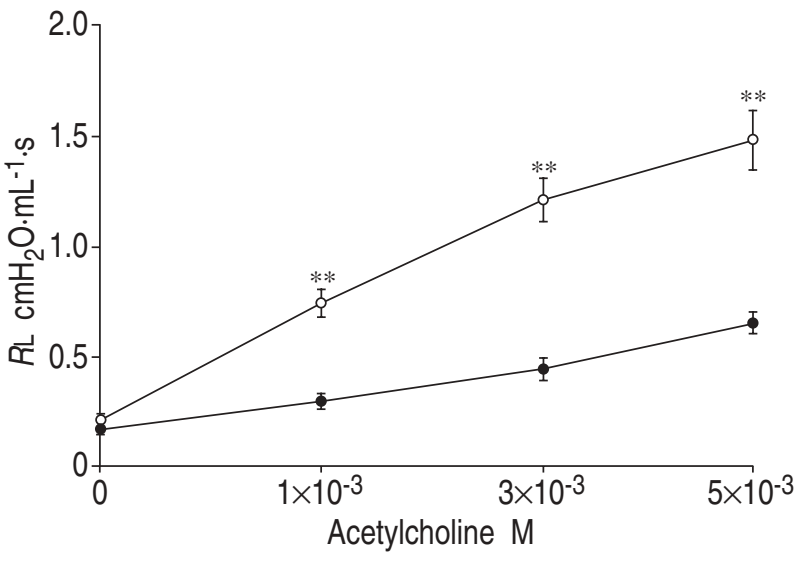

Fig. 5. - Effects of endothelin-1 (ET-1; 10-10 M) on acetylcholine-induced bronchoconstriction. $\bullet$ : solvent; o : ET-1. Each point represents the mean \pm SEM for five animals. **: $\mathrm{p}<0.01$ compared with acetylcholine alone.

However, ET-1 (10-10 M) also potentiated acetylcholineinduced bronchoconstriction. Accordingly, a subthreshold concentration of ET-1 may cause nonspecific bronchial hyperresponsiveness. Although acetylcholine is thought to be a direct smooth muscle constrictor, previous re- ports suggested that the administration of methacholine into guinea-pig airways induced tachykinin release [25]. Further studies will be required to determine whether a subthreshold concentration of ET-1 induces nonspecific airway hyperresponsiveness. A further, third mechanism of ET-1-induced bronchoconstriction is mediated through a neuromodulator effect that potentiates neurally mediated bronchoconstriction [26].

Various effects of ET-1 are mediated via ET receptor, and two subtypes of ET receptor, termed ETA and ETB, have been cloned, sequenced and characterized [27, 28]. In guinea-pig and isolated human bronchial smooth muscle, ET-1-induced contraction is mediated predominantly via activation of the ETB receptor subtype [29, 30]. However, contractions in response to ET-1 in the guinea-pig trachea and lung parenchyma are mediated in part by ETA receptors. In addition, in lung parenchyma, these ETA receptors mediate contraction through the release of cyclooxygenase metabolites induced by relatively high doses of ET-1. In this study, potentiation of capsaicin-induced and tachykinin-induced bronchoconstriction by subthreshold concentration of ET-1 was completely abolished by BQ788, suggesting that low concentrations of ET-1 affect airway responses through ETB receptors alone.

ET-1 acts primarily as a local paracrine and autocrine hormone. Even though ET-1 concentrations in BAL fluid are generally below the threshold level required for contraction of airway smooth muscles, ET-1 levels in local airways are possibly high enough to elicit bronchoconstriction [31]. However, it is also important to determine the physiological effects of a subthreshold concentration of ET-1 acting as a local hormone. A recent study determined that inhaled ET-1 is a potent bronchoconstrictor, with a bronchoconstrictive potency about 100-times that of methacholine in asthmatic patients [32]. Furthermore, it remains to be determined whether or not there are therapeutic advantages in using selective ET receptor antagonists in the treatment of asthma. Further studies will be needed to elucidate and classify the ET receptor subtypes mediating the physiological effects of ET-1 in airway responses.

In conclusion, this study suggests that a subthreshold concentration of endothelin-1 potentiated airway smooth muscle contraction through endothelin-B receptors. The effect was not mediated through enhanced tachykinin release from capsaicin-sensitive nerve endings, but occurred at a postjunctional level.

\section{References}

1. Yanagisawa $\mathrm{M}$, Kurihara $\mathrm{H}$, Kimura $\mathrm{S}$, et al. A novel potent vasoconstrictor peptide produced by vascular endothelial cells. Nature 1988; 332: 411-415.

2. Hay DWP, Henry PJ, Goldie RG. Endothelin and the respiratory system. Trends Pharmacol Sci 1993; 14: 29-32.

3. Vittori E, Marini M, Fasoli A, De Franchis R, Mattoli S. Increased expression of epithelial cells of asthmatic patients and effects pf corticosteroids. Am Rev Respir Dis 1992; 146: 1320-1325.

4. Springhall DR, Howarth PH, Counihan H, Djukanovic R, Holgate S, Polak JM. Endothelin immunoreactivity of airway epithelium in asthmatic patients. Lancet 1991; 337: 697-701.

5. Nomura A, Uchida Y, Kameyama M, Saotome M, Ohi K, Hasegawa S. Endothelin and bronchial asthma. Lancet 1989; ii: 747-748.

6. Filep JG. Endothelin peptides: biological actions and pathophysiological significance in the lung. Life Sci 1993; 25: 119-133.

7. Mattoli S, Soloperto M, Marini M, Fasoli A. Levels of endothelin in the bronchoalveolar lavage fluid of patients with symptomatic asthma and reversible airflow obstruction. J Allergy Clin Immunol 1991; 88: 376-384.

8. Kanazawa H, Kurihara N, Hirate K, Fujiwara H, Matsushita $\mathrm{H}$, Takeda $\mathrm{T}$. Low concentrations of endothelin-1 enhanced histamine-mediated bronchial contractions of guinea-pigs in vivo. Biochem Biophys Res Commun 1992; 187: 717-721.

9. Solway J, Leff AR. Sensory neuropeptides and airway function. J Appl Physiol 1991; 71: 2007-2087.

10. Coleridge JCG, Coleridge HM. Afferent vagal C fiber innervation of the lungs and airways and its functional significance. Rev Physiol Biochem Pharmacol 1984; 99: $1-100$.

11. Coleridge HM, Coleridge JCG. Impulse activity in afferent vagal C-fiber with endings in the intra-pulmonary airways of dogs. Respir Physiol 1977; 29: 125-142.

12. Martins HA, Shore SA, Gerard NP, Gerard C, Drazen JM. Peptidases modulation of the pulmonary effects of tachykinins in tracheal superfused guinea-pig lungs. J Clin Invest 1990; 85: 170-176.

13. Lundberg JM, Sario A, Brodin E, Rosell S, Folkers K. A substance $\mathrm{P}$ antagonists inhibits vagally induced increase in vascular permeability and bronchial smooth muscle contraction in the guinea-pig. Proc Natl Acad Sci USA 1983; 80: 1120-1124.

14. Barnes PJ. Asthma as an axon reflex. Lancet 1986; i: 242-245.

15. Gashi AA, Borson DB, Finkbeiner WE, Nadal JA, Basbaum CB. Neutropeptides granulate serous cells of ferret tracheal glands. Am J Physiol 1986; 251: C223-C229.

16. Mapp CE, Chitano P, Fabbri LM, et al. Evidence that toluene diiscyanate (TDI) activates the efferent function of capsaicin-sensitive primary afferents. Eur J Pharmacol 
1990; 180: 113-118.

17. Dusser DJ, Umeno E, Graf PD, Djokic T, Borson DB, Nadel JA. Airway neutral endopeptidase-like enzyme modulates tachykinin-induced bronchoconstriction in vivo. $J$ Appl Physiol 1988; 65: 2585-2591.

18. Ballati L, Evangelista S, Maggi CA, Manzini S. Effects of selective tachykinin receptor antagonists on capsaicinand tachykinin-induced bronchospasm in anesthetized guinea pigs. Eur J Pharmacol 1992; 214: 215-221.

19. Kanazawa H, Kamoi H, Kawaguchi T, et al. PAMP is a novel inhibitor of the tachkinin release in the airway of guinea pigs. Am J Physiol 1997; 272: L1066-L1069.

20. Mattoli S, Soloperto M, Mezzetti M, Fasoli A. Mechanisms of calcium mobilisation and phosphoinositide hydrolysis in human bronchial smooth muscle cells by endothelin 1. Am J Respir Cell Mol Biol 1991; 111: 1163-1169.

21. Maggi CA, Patacchini R, Giuliani S, Meli A. Potent contractile effect of endothelin in isolated guinea pigs airways. Eur J Pharmacol 1989; 160: 179-182.

22. Filep JG, Battistini B, Sirois P. Pharmacological modulation of endothelin-induced contractions of guinea-pigs isolated airways and thromboxane release. Br J Pharmacol 1991; 103: 1633-1640.

23. Kanazawa H, Fujiwara H, Shoji S, et al. Adenosine modulates endothelin-induced bronchoconstriction in guinea pig airway. Int Arch Allergy Immunol 1997; 112: 83-87.

24. Hay DWP, Hubbard WC, Undem BJ. Endothelin-induced contraction and mediator release in human bronchus. $\mathrm{Br} J$ Pharmacol 1993; 110: 392-398.

25. Martins MA, Shore SA, Drazen JM. Release of tachyki- nins by histamine, methocholine, PAF, $\mathrm{LTD}_{4}$ and substance P from guinea pig lungs. Am J Physiol 1991; 261: L449-L455.

26. Henry PJ, Goldie RG. Potentiation by endothelin-1 of cholinergic nerve-mediated contractions in mouse trachea via activation of ETв receptors. Br J Pharmacol 1995; 114: 563-569.

27. Hosoda K, Nakao K, Tamura N, et al. Organization, structure, chromosomal assignment, and expression of the gene encoding the human endothelin-A receptor. J Biol Chem 1992; 267: 18797-18804.

28. Arai H, Nakao K, Takaya K, et al. The human endothelin$\mathrm{B}$ receptor gene: structural organization and chromosomal assignment. J Biol Chem 1993; 268: 3463-3470.

29. Battistini B, Warner TD, Fournier A, Vane JR. Characterization of ETB receptors mediating contractions induced by endothelin-1 or IRL1620 in guinea pig isolated airways: efects of BQ123, FR139317 or PD145065. $\mathrm{Br} \mathrm{J}$ Pharmacol 1994; 111: 1009-1016.

30. Goldie RG, Henry PJ, Knott PG, Self GJ, Luttmann MA, Hay DWP. Endothelin-1 receptor density, distribution, and function in human isolated asthmatic airways. Am J Respir Crit Care Med 1995; 152: 1653-1658.

31. Redington AE, Springall DR, Ghatei MA, et al. Endothelin in bronchoalveolar lavage fluid and its relation to airflow obstruction in asthma. Am J Respir Crit Care Med 1995; 151: 1034-1039.

32. Chalmers GW, Little SA, Patel KR, Thompson NC. Endothelin-1-induced bronchoconstriction in asthma. Am J Respir Crit Care Med 1997; 156: 382-388. 